\title{
GNA13 wt Allele
}

National Cancer Institute

\section{Source}

National Cancer Institute. GNA13 wt Allele. NCI Thesaurus. Code C115329.

Human GNA13 wild-type allele is located in the vicinity of $17 q 24.3$ and is approximately $48 \mathrm{~kb}$ in length. This allele, which encodes guanine nucleotide-binding protein subunit alpha-13 protein, is involved in signaling that is regulated by heterotrimeric $\mathrm{G}$ proteins. 